Res Mobilis

Revista internacional de investigación en mobiliario y

objetos decorativos

Vol. 2, nº. 2, 2013

\title{
MUEBLES DE GUARDAR. ARCAS Y ARMARIOS DE LOS SIGLOS XIV AL XX: UNA EXPOSICIÓN COMO DECLARACIÓN DE INTENCIONES EN EL MUSÉU DEL PUEBLU D'ASTURIES
}

Gerardo Díaz Quirós*

Doctor Historia del Arte

Entre marzo y noviembre de 2013 pudo verse en el Muséu del Pueblu d'Asturies de Gijón, bajo el título de Muebles de guardar. Arcas y armarios de los siglos XIV al $X X$, la primera exposición sobre mueble que se monta en el Principado. A pesar de la riqueza interpretativa del mueble, de la estrecha vinculación histórica de Asturias con la madera y sus oficios o de la larga y fecunda tradición de la talla popular, los estudios sobre mobiliario en Asturias han sido, hasta fecha reciente, extraordinariamente escasos. De igual modo, la perenne precariedad de los museos -muy especialmente de los de orientación etnográfica-, sin apenas fondos para adquisiciones, sin personal especializado y hasta sin espacio de almacén, no favoreció la generación de colecciones públicas de mueble. La invitación cursada por el Muséu del Pueblu d'Asturies resulta, por tanto, aún en su modestia, plenamente excepcional. Además de los fondos del propio museo gijonés, se allegaron piezas, en este caso, de la colección del Museo Arqueológico de Asturias (materiales donados por los herederos del Marqués de la Rodriga y adquisiciones de José Fernández Buelta por indicación de la Diputación Provincial), del Museo Marítimo de Asturias, de la Parroquia Rural de Leitariegos, de la Colegiata de Salas y de alguno particulares.

Instalada en la pequeña sala de exposiciones temporales del que fuera Pabellón de Asturias en la Exposición Universal de Sevilla de 1992, la muestra gira en torno a los muebles de guardar, aunque estarán representados exclusivamente arcas (ocho arcas, tres frentes de arca desarmados y dos arquetas) baúles (tres piezas, una de ellas un Baúl mundo) y armarios (seis). Se completa con seis proyectos sobre papel iluminados a la acuarela de Casa Del Río, una de las firmas más afamadas en el panorama de la decoración de interiores en Asturias desde el último cuarto del siglo XIX. Es evidente que otras tipologías de mueble podrían haberse integrado en la exposición sin forzar la primera parte del discurso que sintetiza su título, pero quizá está en la cómoda la ausencia más llamativa, pues habría reflejado la transición del arca al armario y dado pie al

*E-mail: diazgerardo@hotmail.com 
repaso de una evolución estilística particularmente rica. Se exponen, en todo caso, piezas extraordinarias, como el arca de tres llaves del antiguo concejo de Leitariegos, fechada en el siglo XIV, excelentes obras del siglo XVIII y una solvente cita respecto a la presencia de la hexapétala en los frentes de arcas asturianas. Aunque más desiguales en calidad, armarios y baúles son eficaces para completar la idea propuesta. Un pequeño catálogo de cuidada maquetación y profusamente ilustrado, presentado exclusivamente en versión digital, complementa la exposición, en torno a la que se programó, además, un ciclo de conferencias.

Ejecutada con muy pocos medios, la exposición no pretende ofrecer al espectador una síntesis acabada de la evolución del mobiliario en Asturias, de riqueza mucho mayor a la que consigue evocar la muestra, pero puede ser leída, sobre todo, como una declaración de intenciones: testimonio de la conciencia clara por parte de la dirección de museo -no en vano su director se cuenta entre los primeros investigadores en estudiar de forma sistemática algunos aspectos relacionados con el mueble popular en Asturias- de las posibilidades del tema; defensa de la rica condición estética y documental del mueble; deseo de ofrecer a los asturianos en una pincelada un mundo poco conocido y con el que cabe establecer un enriquecedor diálogo creativo en el presente. Cabe esperar que en un futuro próximo se pueda hablar de esta cita como antesala de grandes exposiciones sobre mueble en Asturias. 